\title{
Assessing China's energy conservation and carbon intensity: how will the future differ from the past?
}

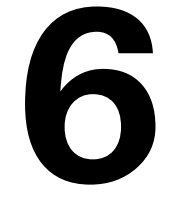

\section{ZhongXiang Zhang}

\section{Introduction}

China's spectacular economic growth since 1978 has been heavily dependent on burning dirty coal. This has given rise to unprecedented environmental pollution and health risks. On top of these domestic environmental stresses, projected global climate change is expected to pose additional threats to China in the foreseeable future.

As the world's largest emitter of carbon dioxide, China is facing great pressure inside and outside international climate negotiations to be more ambitious in combating climate change. China cannot afford to continue on the conventional path of encouraging economic growth at the expense of the environment, whether it looks at the issue from a domestic or international perspective. A range of environmental concerns and pressures has sparked China's determination to improve energy efficiency and to increase the use of clean energy in order to help its transition to a low-carbon economy.

China achieved a quadrupling of its gross domestic product (GDP) with only a doubling of energy consumption between 1980 and 2000 (Zhang 2003). Following the trends of the 1980s and 1990s, the US Energy Information Administration (EIA 2004) estimated that China's carbon dioxide emissions were not expected to catch up with the world's largest carbon emitter until 2030. China's energy use has, however, surged since the turn of this century - almost doubling between 2000 and 2007. Although rates of economic growth were similar in the two periods, the rate of growth in China's energy use during this period (9.7 per cent per annum) was more than twice that of the previous two decades ( 4.25 per cent per annum) (NBS 2009). This change in energy intensity was responsible for an increase of 20 million tonnes of carbon emissions ( $\mathrm{mtc}$ ) during the period 200107, compared with a reduction of 576 mtc during the period 1980-2000 (Zhang 2009d). As a result, China became the world's largest carbon emitter in 2007. 
To reverse this trend, China has incorporated a requirement that energy use per unit of GDP (energy intensity) be cut by 20 per cent during the eleventh five-year-plan period, running from 2006 to 2010. This is widely considered an important step towards building a 'harmonious society' through 'scientific development'. Just before the Copenhagen climate summit, China further pledged to cut its carbon intensity by $40-45$ per cent by 2020 relative to its 2005 levels in order to help reach an international climate change agreement at Copenhagen or beyond.

This chapter focuses on assessing China's energy conservation to date and its proposed carbon intensity target. ${ }^{1}$ It first discusses China's own efforts towards saving energy, cutting pollution and promoting the widespread use of renewable energy. Next, to put China's proposed carbon intensity target into perspective, the chapter seeks to answer a number of issues related to the proposed carbon intensity goal for 2020: is the target as challenging as the energy-saving goals set in the current eleventh five-year economic blueprint; to what extent would it drive China's emissions below projected baseline levels; and if the commitment were met, would China will fulfil its proportionate part of a coordinated global commitment to stabilise the concentration of greenhouse gas emissions in the atmosphere at the level that the Copenhagen meeting agreed was desirable.

As long as China's pledges are in the form of carbon intensity, the reliability of emissions and GDP data matters. The chapter goes on to address reliability issues concerning China's statistics on energy and GDP. Given that China has shifted control over resources and decision-making to local governments during the past three decades, effective environmental protection must be placed in the context of government decentralisation.

The chapter concludes that there is a need to carefully examine those objective and subjective factors that lead to the lack of local officials' cooperation with national policy on the environment, and also that strict implementation and coordination of official policies and measures are of paramount importance in meeting China's existing energy-saving goal in 2010, its proposed carbon intensity target in 2020 and whatever climate commitments China adopts for beyond 2020 .

1 See Zhang $(2000,2009 a, 2009 b, 2009$ c) for detailed discussion of China's climate strategies regarding the format and time frame that it would take on climate commitments. 


\section{Increasing energy efficiency and cutting pollutants}

While China has been calling for energy savings since the early 1980s, the quantitative target on energy efficiency in the current five-year (2006-10) economic plan is an important new development.

China achieved a quadrupling of its GDP with only a doubling of energy consumption between 1980 and 2000 (Figure 6.1). However, from 2002 China experienced faster growth of energy consumption than of economic output, which translates into rising energy intensity. The changing trend on energy efficiency reflects the completion by about the turn of the century of the reductions of energy use associated with the movement towards market pricing of energy as a result of reforms in the 1980s and 1990s. The change in the trajectory of energy intensity that is necessary to meet the new targets suggests that the attainment of the targets will be extremely challenging (Zhang 2005, 2007d).

Industry accounts for about 70 per cent of the country's total energy consumption (Zhang 2003), so that this sector is crucial for China to meet its own goal. The Chinese government has made great efforts towards changing the current energy-inefficient and environmentally unfriendly pattern of industrial growth. China is exploring industrial policies to promote industrial upgrading and energy conservation. With a surge in energy use in heavy industry, the Chinese government started levying export taxes in November 2006 on energy and resource-intensive products to discourage their export and to save scarce energy and resources. These include a 5 per cent export tax on oil, coal and coke; a 10 per cent tax on revenues from sale of non-ferrous metals, some minerals and 27 other iron and steel products; and a 15 per cent tax on revenues from copper, nickel, aluminium and other metallurgical products. ${ }^{2}$

From July 2007, China eliminated or cut export tax rebates under the value added tax for 2831 export items. This is considered the boldest move to rein in exports since China joined the World Trade Organisation (WTO). Among the affected items - which account for 37 per cent of all traded products - are 553 highly energy-consuming, highly-polluting and resource-intensive products, such as cement, fertiliser and non-ferrous metals. The export tax rebates on these products were completely eliminated. This policy will help to enhance energy efficiency and rationalise energy and resource-intensive sectors as well as contribute to macro-economic policy objectives (Zhang 2008).

2 See Zhang (2009c) for discussion of links between China's own export taxes and carbon tariffs proposed in US climate legislation. 
On the energy-saving front, China established the 'Top 1000 Enterprises Energy Conservation Action Program' in April 2006. This program covers 1008 enterprises in nine key energy supply and consuming industrial sub-sectors. These enterprises each consumed at least 180000 tonnes of coal equivalent (tce) in 2004, and together consumed 33 per cent of the national total and 47 per cent of industrial energy consumption in 2004. The program aims to save 100 million tce cumulatively during the period 2006-10, thus making a significant contribution to China's overall goal of a 20 per cent energy intensity improvement (NDRC 2006a). In May 2006, empowered by the State Council, the National Development and Reform Commission (NDRC), China's top economic planning agency, signed energy-saving responsibility agreements with these enterprises. To ensure that the goal is met, achieving energy efficiency improvements has become a criterion for job performance evaluations of the heads of these enterprises. The first year's results of the program's implementation are encouraging, with more than 95 per cent of these enterprises appointing energy managers and the program achieving energy savings of 20 million tce in 2006 (NDRC and NBS 2007). In 2007, 38.2 million tce of energy was saved-almost doubling the amount of energy saved in 2006. If savings continue at the 2007 rate, the top-1000 program will exceed its target (NDRC 2008b).

\section{Figure 6.1 Energy use per unit of GDP in China, 1990-2007 (tonnes of coal equivalent per US\$1000 in 1980 prices)}

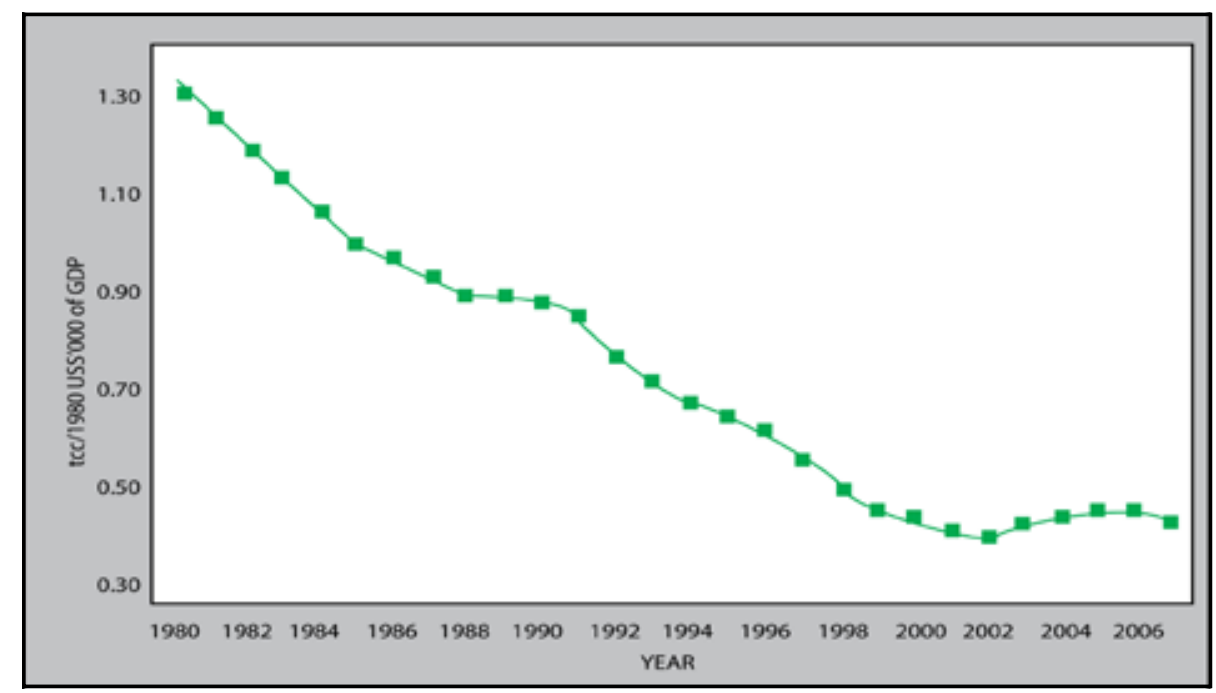

Source: Based on National Bureau of Statistics (NBS) various years, China Statistical Yearbook, China Statistics Press, Beijing. 
Power generation is the largest coal consumer, currently consuming more than half of the total used in China. This share is expected to rise well above 60 per cent in 2020. Thus, efficient coal combustion and power generation is of paramount importance to China's energy savings and pollution reduction. To that end, China has adopted a policy of accelerating the closure of thousands of small, inefficient coal and oil-fired power plants. Units facing closure include those below 50 megawatts (MW), those below $100 \mathrm{MW}$ and in operation for more than 20 years, those below $200 \mathrm{MW}$ and having reached the end of their design life, those with a coal consumption per unit of power output 10 per cent higher than the provincial average or 15 per cent higher than the national average, and those that fail to meet environmental standards. The total combined capacity to be decommissioned is set at 50 gigawatts (GW) during the period 2006-10. By the end of 2008, China had closed small plants with a total capacity of $34.2 \mathrm{GW}$, relative to a total capacity of $8.3 \mathrm{GW}$ decommissioned during the period 2001-05 (NDRC 2008a). By the end of the first half of 2009, the total capacity of decommissioned smaller and older units had increased to $54 \mathrm{GW}$, meeting the 2010 target one and half years ahead of schedule ('SO2 cutting goal expected to come ahead of schedule', 7 July, Sina Net, <http://finance.sina.com. cn/roll/20090707/04346447872.shtml>).

The Chinese government's policy has concurrently focused on encouraging the construction of larger, more efficient and cleaner units. By 30 June 2009, 64 per cent of coal-fired units had capacities of $300 \mathrm{MW}$ or more (Wang and Ye 2009). China's power industry has listed supercritical power generation technology as a key development focus due to its higher thermal efficiency and relatively low unit investment costs. As a result, an increasing number of newly built plants are more efficient supercritical (SC) or ultra-supercritical (USC) plants. By 2007, the share of SC and USC units in total coal-fired generation capacity was about 12 per cent. In comparison, the corresponding share is about 70 per cent in Japan and 30 per cent in the United States. The share of USC plants in total coalfired generation capacity is expected to grow to 15 per cent by 2010 and 30 per cent by 2020 (Huang 2008; IEA 2009a).

For residential buildings, China has taken three steps to improve energy efficiency. The first step requires a 30 per cent cut in energy use relative to typical Chinese residential buildings designed in 1980-81. Second, China requires that new buildings be 50 per cent more efficient by 2010. Third, the energy-saving goal is to be increased to 65 per cent for new buildings by 2020 (Zhang 2005, 2008). Tianjin is the first metropolitan city in China to embark on reform of heat supply and charges. By the end of 2006, 73.5 million square metres of energyefficient residential building space had been built in this city, accounting for 48 per cent of total residential buildings (Zheng and You 2007). In Beijing, the building sector consumed 28 per cent of total energy use in 2004. By the end 
of 2004, 175.2 million sq $\mathrm{m}$ of energy-efficient residential building space had been built in China's capital, 37 per cent of which met the requirement for a 30 per cent increase in energy efficiency. The remaining 62.9 per cent met the '50 per cent more energy-efficient' standards. These energy-efficient buildings in Beijing accounted for 65 per cent of its total residential buildings. Beijing's plan is for all new residential buildings to meet the ' 65 per cent more energy-efficient' standards by 2010 - one decade ahead of the national schedule (BMCDR 2006).

In the transport sector, the excise tax for vehicles has been adjusted over time to provide incentives for the purchase of energy-efficient cars. The excise tax levied at the time of purchase was first introduced in 1994. The rate increases with the size of the engine - set at 3 per cent for cars with engines of 1 litre or less, 8 per cent for cars with engines of more than 4 litres and 5 per cent for cars with engines in between. These tax rates for cars remain unchanged. The new vehicle excise tax, implemented since April 2006, has broadened the tax base from the existing range of 3-8 per cent to 3-20 per cent and to six categories of engine size. Table 6.1 demonstrates clearly the large, upward adjustment in the consumption tax on fuel-guzzling cars over time. Moreover, China cut the purchase tax rate for cars with engines of 1.6 litres or less from the normal rate of 10 per cent to 5 per cent in 2009 and 7.5 per cent in 2010. While this rate cut is motivated by the need to stimulate the economy during the economic crisis, it practically benefits saving energy and cutting pollution as well.

Table 6.1 Consumption tax rates for cars in China (per cent)

\begin{tabular}{lccc}
\hline Engine size (litres) & $\begin{array}{c}\text { Excise tax since } \\
\text { 1 January 1994 }\end{array}$ & $\begin{array}{c}\text { Excise tax since } \\
\text { 1 April 2006 }\end{array}$ & $\begin{array}{c}\text { Excise tax since } \\
\text { 1 September 2008 }\end{array}$ \\
\hline 1.0 or less & 3 & 3 & 1 \\
$1.0<$ engine $\leq 1.5$ & 5 & 3 & 3 \\
$1.5<$ engine $\leq 2.0$ & 5 & 5 & 5 \\
$2.0<$ engine $\leq 2.5$ & 5 & 9 & 9 \\
$2.5<$ engine $\leq 3.0$ & 5 & 12 & 12 \\
$3.0<$ engine $\leq 4.0$ & 5 & 15 & 25 \\
Greater than 4.0 & 8 & 20 & 40 \\
\hline
\end{tabular}

Sources: 'Special topic on paying close attention to adjustments in consumption tax policy, Sina Net, $<$ http://finance.sina.com.cn/focus/gzxfstz/index.shtml>; 'Adjustments for vehicle excise taxes will take place since September 1, up for cars with large engines and down for small cars to 1 per cent', People Net, 14 August, <http://auto.people.com.cn/GB/1049/7663221.html>

China has set fuel economy standards for its rapidly growing passenger vehicle fleet even more stringent than those in Australia, Canada and the United States, although they are less stringent than those in Japan and the European Union (Figure 6.2). Implemented in two phases, the standards classify vehicles into 16 weight classes, covering passenger cars, sports utility vehicles (SUVs) and multipurpose vans. Converted to the US Corporate Average Fuel Economy 
(CAFE) test cycle, new vehicles' average fuel economy standards in China are projected to reach 36.7 miles per gallon (6.5 litres per $100 \mathrm{~km}$ ) in 2008 (An and Sauer 2004).

\section{Figure 6.2 Comparison of fuel economy standards for vehicles}

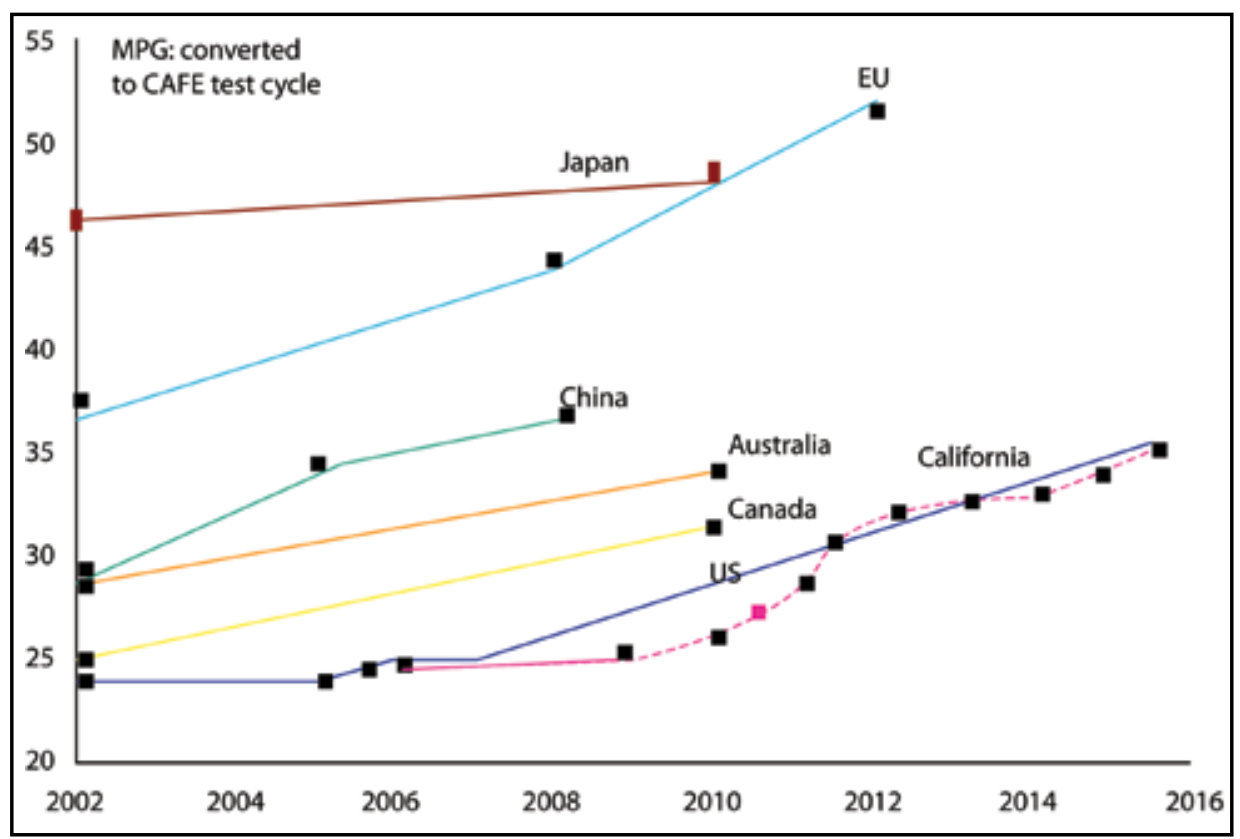

Notes: Dotted lines denote proposed standards; MPG = miles per gallon.

Source: Adapted from An, F. and Sauer, A. 2004, Comparison of Passenger Vehicle Fuel Economy and GHG Emission Standards Around the World, December, Pew Center on Global Climate Change, Arlington, Va, $<$ http://www.pewclimate.org/docUploads/Fuel per cent20Economy per cent20and per cent20GHG per cent20Standards_010605_110719.pdf>

In the meantime, growing Chinese cities are giving priority to public transport and are promoting efficient public transport systems. Given an inevitable increase in the number of vehicles on the road, however, China has also taken significant steps to control vehicle emissions. After the phasing out of leaded gasoline nationwide in July 2000, the State Environmental Protection Agency of China requires all new light-duty vehicles sold after April 2001 to meet State Phase I (similar to Euro I) vehicle emission standards and after 1 July 2004 to meet State Phase II (similar to Euro II) standards across China. Beginning on 1 July 2007, China started implementing State Phase III (similar to Euro III) vehicle emission standards, with State Phase IV (similar to Euro IV) vehicle emission standards scheduled to be introduced on 1 July 2010 (Table 6.2). Pollution from the State Phase III standards is 30 per cent lower than that from State Phase II standards. Pollution from State Phase IV standards goes below 60 per cent of that from State Phase II standards ('Delays in the implementation of state phase 
III vehicle emission standards', Xinhua Net, 7 July, <http://auto.sina.com.cn/ news/2007-07-07/1015290457.shtml>). Clearly, vehicle emission standards in China have become increasingly stringent over time. New vehicles that do not comply with the new standards cannot be sold in China. While China is at about the same levels of vehicle emission standards as India and most Association of South-East Asian Nations (ASEAN) countries, it is a couple of years ahead of these countries in its schedules to implement these regulations. Also, while China still lags behind the European Union's emissions requirements for new vehicles, the gap with the EU requirements has gradually been reduced - from about nine years in 2001 to five and a half years in 2010. Clearly, these new standards will help to reduce substantially environmental costs.

Table 6.2 Vehicle emission standards and the time to enter into force in China, ASEAN and the European Union

\begin{tabular}{|c|c|c|c|c|c|}
\hline Region & Euro I & Euro II & Euro III & Euro IV & Euro V \\
\hline $\begin{array}{l}\text { European } \\
\text { Union }\end{array}$ & $\begin{array}{l}\text { July } \\
1992\end{array}$ & $\begin{array}{l}\text { January } \\
1996\end{array}$ & $\begin{array}{l}\text { January } \\
2000\end{array}$ & $\begin{array}{l}\text { January } \\
2005\end{array}$ & $\begin{array}{l}\text { September } \\
2009\end{array}$ \\
\hline China & $\begin{array}{l}\text { April } \\
2001\end{array}$ & $\begin{array}{l}\text { July } \\
2004\end{array}$ & $\begin{array}{l}\text { July } \\
2007\end{array}$ & $\begin{array}{l}\text { July } \\
2010\end{array}$ & \\
\hline Beijing & 1999 & $\begin{array}{l}\text { August } \\
2002\end{array}$ & $\begin{array}{l}\text { December } \\
2005\end{array}$ & $\begin{array}{l}\text { First half } \\
2008\end{array}$ & \\
\hline India & 2000 & 2005 & 2010 & & \\
\hline ASEAN & & $\begin{array}{l}\text { December } \\
2005 \\
\text { (targeted) }\end{array}$ & & $\begin{array}{l}\text { December } \\
2010 \\
\text { (targeted) }\end{array}$ & \\
\hline Indonesia & & Early 2006 & $\begin{array}{l}\text { First quarter } \\
2007\end{array}$ & 2012 & \\
\hline Malaysia & & Mid 2006 & & 2010 & \\
\hline Philippines & & $\begin{array}{l}\text { December } \\
2006\end{array}$ & & 2010 & \\
\hline Singapore & & 2005 & & $\begin{array}{l}\text { October } \\
2006 \text { (diesel) }\end{array}$ & \\
\hline Thailand & & & $\begin{array}{l}\text { Early } \\
2005\end{array}$ & 2010 & \\
\hline Vietnam & & $\begin{array}{l}\text { July } \\
2007\end{array}$ & & 2012 & \\
\hline
\end{tabular}

Source: Zhang, Z. X. 2008, 'Asian energy and environmental policy: promoting growth while preserving the environment', Energy Policy, vol. 36, pp. 3905-24.

\section{The use of renewable energy}

Concerns about climate change and other environmental problems and health risks have sparked China's plans to pursue alternative energy sources to meet 
the country's increasing energy needs. China has targeted alternative energy sources to meet up to 15 per cent of the nation's energy requirements by 2020 up from 8.9 per cent in 2008. While this is a big step up from the previous goal of 10 per cent by 2020, early success is encouraging officials to develop even more ambitious targets. Under the plan as its stands, China aims to have an installed capacity of $300 \mathrm{GW}$ for hydropower (including large hydropower), 30 GW for wind power and $30 \mathrm{GW}$ for bio-power (power generated from biomass), and to produce 10 million tonnes of ethanol and 2 million tonnes of bio-diesel by 2020 (Zhang 2007b).

The European Union is widely considered to be the world's leader in renewable energy. The European Union is aiming for renewable energy to meet 12 per cent of its primary energy by 2010 and 20 per cent by 2020 from its current level of 6.5 per cent (European Commission 2007a, 2007b). At first glance, the European Union's goal of tripling the share of renewable energy from the current level to 20 per cent by 2020 seems even more ambitious than China's renewable energy goal. Because energy demand in China grows at least three times faster than in the European Union, doubling renewable energy in China's total energy mix by 2020 requires renewable energy in China to grow at a rate four times that in the European Union.

In addition to setting extremely ambitious renewable energy goals, China is making large efforts to meet these goals. China invested US\$34.6 billion in renewable energy in 2009, causing the United States to lose the top spot for the first time in five years, coming in a distant second with a total investment of US\$18.6 billion. In terms of renewable energy investment as a percentage of GDP, China, with 0.39 per cent, invested three times more than the United States, with 0.13 per cent, in 2009 . With an installed capacity of $52.5 \mathrm{GW}$, China ranked second in the world's total renewable energy capacity in 2009-just slightly behind the United States, with 53.4 GW (Pew Charitable Trusts 2010).

With wind power identified as a priority for diversifying China's energy mix, this sector has been the primary recipient of renewable energy investment and favourable policies in recent years. In 2003, China adopted the Wind Power Concession Program as its primary strategy to further promote wind power development. Feed-in tariffs enacted in 2005 took effect on 1 January 2006. This government-run program auctions off development rights for wind power projects of $100 \mathrm{MW}$ or more for a 25-year period, which includes a guaranteed tariff for the first 30000 hours as well as concessionary operation agreements. This on-grid wind power tariff is decided through a competitive bidding process. If the tariff is higher than the reference on-grid tariff of de-sulphurised coal-fired power, the difference will be shared in the selling price at the provincial and national grid levels. For the remainder of the period (namely, after the first 30 000 hours until the ending of the total concession period of 25 years), the wind 
power tariff is set to be equal to the average local on-grid tariff. Other policies have included a halving of the value-added tax (VAT) for wind power, from the normal rate of 17 per cent to 8.5 per cent; lower duty rates levied on domestic investment in wind power (6 per cent compared with the normal rate of 23 per cent); and no duties for equipment imported for renewable energy technologies in joint ventures. Some local governments have provided even more favourable policies. For example, in Inner Mongolia, a VAT of 6 per cent is levied on wind power.

With these favourable policies in place, the total wind power capacity installed doubled between 2003 and 2005, reaching 1.3 GW in 2005. With China's Renewable Energy Law entering into force in January 2006, the pace of installations accelerated considerably. The total installed wind power capacity rose to $2.6 \mathrm{GW}$ in 2006, with new installations in that year alone amounting to more than the combined total in the past 20 years. Wind power capacity in China has doubled in each of the past five years (Figure 6.3). With total installed capacity of $5.9 \mathrm{GW}$ at the end of 2007, China had already surpassed its goal to achieve $5 \mathrm{GW}$ by 2010. With new installations of $6.3 \mathrm{GW}$ and a total installed capacity of $12.2 \mathrm{GW}$ in 2008, China overtook India in wind power installations. During this process, local wind turbine makers - such as Sinovel Wind, Goldwind Science and Technology and Dongfang Electric - accounted for an increasing share of total new installations. Together, they now supply more than 50 per cent of a market dominated by foreign firms until 2008. Sinovel and Goldwind are now among the world's top-five turbine manufacturers.

In its response to the economic crisis, the Chinese government has identified the development of wind power as an area of economic growth. With new installations of $13.8 \mathrm{GW}$ in China-relative to that of $10 \mathrm{GW}$ in the United States - China overtook the United States as the world's top wind power market in 2009. With a total installed capacity of $25.8 \mathrm{GW}$, China slipped past Germany to take second place in total wind power installations in 2009 (Global Wind Energy Council 2010). While the United States continues to have a comfortable lead in terms of total installed capacity, at this growth rate of new capacity installations, China will overtake the United States in 2010 to become the global leader in installed capacity and will have met its 2020 target of $30 \mathrm{GW} 10$ years ahead of schedule. Indeed, since 2008, China has been planning and designing the 'mega-wind power base program', which aims to build a combined wind capacity of $127.5 \mathrm{GW}$ by 2020 in six selected Chinese provinces. This program is expected to increase China's total installed capacity of wind power to $150 \mathrm{GW}$ or more by 2020 - five times the 30 GW target set as late as September 2007. 
Figure 6.3 Cumulative installed wind power capacity by country, 1980-2009

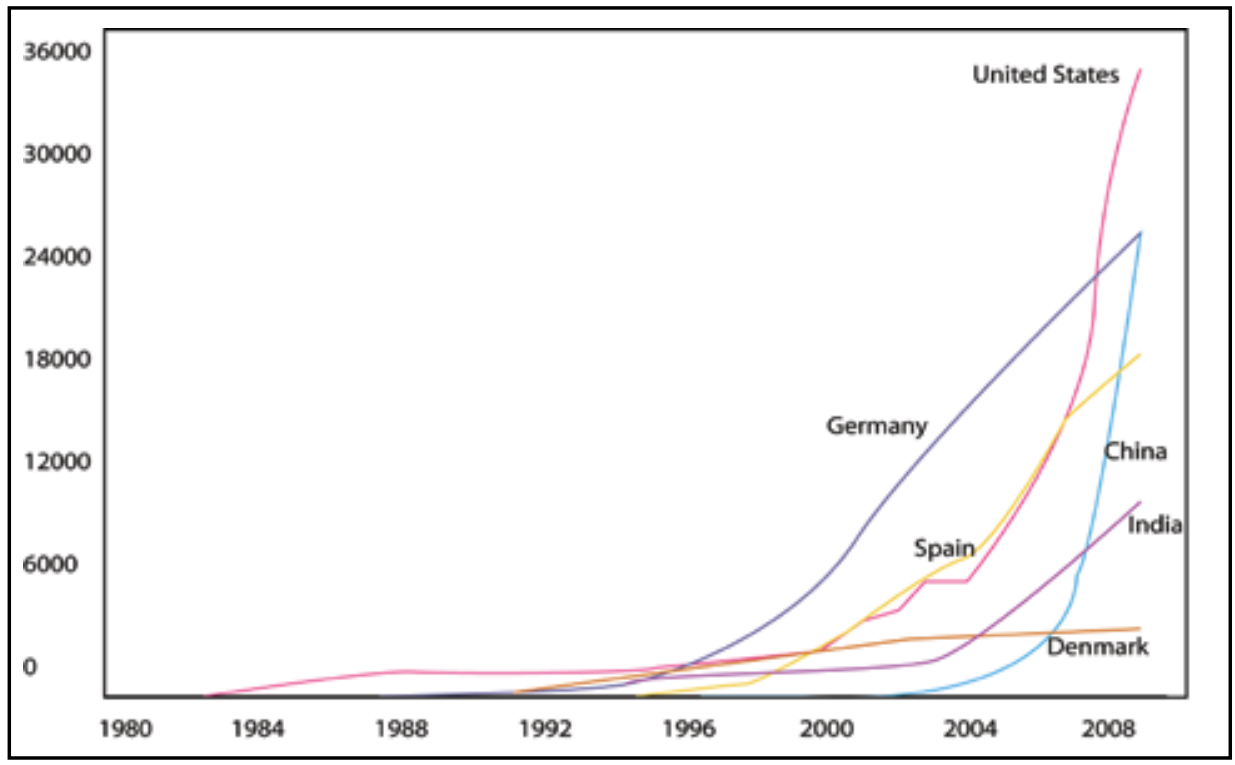

Sources: Based on data from Global Wind Energy Council 2010, Global Wind 2009 Report, March, Global Wind Energy Council, Brussels, <http://www.gwec.net/fileadmin/documents/Publications/Global_ Wind_2007_report/GWEC_Global_Wind_2009_Report_LOWRES_15th. per cent20Apr..pdf >; Earth Policy Institute 2008, Global Wind Power Capacity Reaches 100,000 Megawatts, 4 March, Earth Policy Institute, Washington, DC, <http://www.earth-policy.org/Indicators/Wind/2008.htm>

With both power demand and new installations of wind power capacity increasing faster than planned, and further deterioration of the environment, China is set to raise its wind power target. The country now aims to have at least $100 \mathrm{GW}$ of wind power capacity in operation by 2020. This revised target is $70 \mathrm{GW}$ higher than the current target, four times its current total wind power capacity and more than the United Kingdom's entire current power capacity. In addition, the NDRC enacted feed-in tariffs for wind power, which took effect on 1 August 2009. This means the end of the controversial bidding-based program that had been in place since 2003. According to the quality of wind energy resources and the conditions of engineering construction, four wind energy areas are classified throughout China. Accordingly, on-grid tariffs are set at RMB0.51, RMB0.54, RMB0.58 and RMB0.61 per kilowatt hour (kW.h) as benchmarks for wind power projects across the nation (NDRC 2009). The levels are comparable with the tariffs the NDRC approved in the past several years in most regions and are substantially higher than those set through bidding. By letting investors know the expected rate of return on their projects through announcing on-grid tariffs, the Chinese government aims to encourage the development of wind energy resources of good quality. In the meantime, this will encourage wind 
power plants to reduce the costs of investment and operation and increase their economic efficiency, thus promoting the healthy development of the whole wind industry in China.

It should be emphasised, however, that while China has established a very ambitious wind power target, many local power grids are simply too small to carry all the wind power being generated. Wind turbines often have to wait four months or more before they are hooked up to the power grid. Of $5.9 \mathrm{GW}$ of total installed capacity at the end of 2007, only 4 GW were plugged into the grid (Cyranoski 2009). In the first quarter of 2010, the amount of wind power not used because it was not hooked into the grids reached almost 0.3 terawatt hours (TW.h). This is a significant amount of generation, given that the total wind power generation reached only 0.5 TW.h in the same period (Chen 2010). Thus, China needs to improve its power grids and coordinate the development of wind power with the planning and construction of power grids. New transmission lines will have to be constructed as more wind farms are built. Moreover, given the significantly increased wind power capacity planned for 2020, China should now place more emphasis on companies ensuring the actual flow of power to the grid rather than just meeting capacity. Improving the quality of domestically made turbines is crucial for this endeavour. While less costly, domestic Chinese wind turbines break down more often and have overall capacity factors several percentage points lower than foreign models. This few percentage points difference could make a difference between a wind farm that is economically viable and one that is not.

\section{China's proposed carbon intensity target: ambitious or business as usual?}

Just before the Copenhagen climate summit, China pledged to cut its carbon intensity by 40-45 per cent by 2020 relative to its 2005 levels. A lot of discussion has since focused on whether such a pledge is ambitious or just represents business as usual (for example, Qiu 2009). China considers it very ambitious, whereas some Western scholars (for example, Levi 2009 but not Garnaut et al. 2009) view it as just business as usual. There are several ways to evaluate this issue.

One way is to see whether this proposed carbon intensity goal for 2020 is as challenging as the energy-saving goals set in the current eleventh five-year economic blueprint. This requires first the establishment of why the current 20 per cent energy-saving goal is considered very challenging. As discussed earlier, China set a goal of cutting energy use per unit of GDP by 20 per cent by 2010 relative to its 2005 levels. In 2006 - the first year of this energy efficiency 
drive - while China reversed the rise in its energy intensity in the first half of the year, energy intensity declined by only 1.8 per cent over the entire year. Although this decline was a first since 2003, it was far short of the targeted 4 per cent. Among the 31 Chinese provinces or equivalent, only Beijing met that energy-saving goal in 2006, cutting its energy use per unit of GDP by 5.3 per cent, followed by Tianjin, another metropolitan city in China, with an energy intensity reduction of 4 per cent, Shanghai by 3.7 per cent, Zhejiang by 3.5 per cent and Jiangsu by 3.5 per cent (NBS et al. 2007). ${ }^{3}$ In 2007, despite concerted efforts towards saving energy, the country cut its energy intensity by 4 per cent (NBS et al. 2009). Beijing continued to take the lead, cutting its energy intensity by 6 per cent, followed by Tianjin by 4.9 per cent and Shanghai by 4.7 per cent (NBS et al. 2008). This clearly indicated Beijing's commitment to the 2008 'Green' Olympic Games. In the meantime, however, there were seven provinces whose energy-saving performances were below the national average. The first year in which China exceeded the overall annualised target (4.4 per cent) for energy savings was 2008, when it cut its energy intensity by 4.6 per cent (NBS et al. 2009). This was due partly to the economic crisis that reduced overall demand-in particular, the demand for energy-intensive products. Overall, energy intensity was cut by 10.1 per cent in the first three years of the plan relative to 2005 levels. This suggests that the country needs to achieve almost the same overall performance in the remaining two years as it did in the first three years in order to meet that national energy intensity target. Moreover, as discussed in the next section, these reductions in China's energy intensity have already factored in the revisions of China's official GDP data from the second nationwide economic census - part of the government's continuing efforts to improve the quality of its statistics, the accuracy of which has been questioned by many inside and outside China. Such revisions show that China's economy grew faster and shifted more towards services than previously estimated, thus benefiting the energy-intensity indicator. Even so, it will not be easy for China to achieve its 20 per cent energy-saving goal. The new carbon intensity target set for 2020 requires an additional 20-25 per cent reduction in emissions intensity, on top of the effects of the existing energy intensity target. Achieving this will clearly be even more challenging and costly for China.

How far does this carbon intensity target drive China's emissions below its projected baseline levels? If this is met, does China play its proportionate part in a coordinated global commitment to stabilise the concentration of greenhouse gas emissions in the atmosphere at the desirable level? The World Energy Outlook 2009 (IEA 2009b) has incorporated many policies into the baseline projection that were not incorporated in the World Energy Outlook 2007 (IEA 2007). This projection puts China's baseline carbon emissions at 9.6 gigatonnes of carbon

3 See Zhang (2007a, 2007c, 2007d) for detailed discussion of why Beijing recorded the most success in achieving its energy-saving goals. 
dioxide (GtCO2) in 2020. Under the ambitious parts per million (ppm) of carbon dioxide equivalent scenario, China's carbon dioxide emissions are projected to be 8.4 GtCO2 by $2020-1.2$ GtCO2 less than that in the baseline (IEA 2009b). Now let us put China's proposed carbon intensity target into perspective. My own calculations show that cutting carbon intensity by $40-45$ per cent in the period 2006-20 would bring reductions of 0.46-1.2 GtCO2 in 2020, which is equivalent to a deviation of 4.8-12.7 per cent below the World Energy Outlook 2009 baseline set for China in 2020. Two key points need to be made. First, even the lower end of that range does not represent business as usual, because it represents a deviation of 4.8 per cent below the World Energy Outlook 2009 baseline levels. Second, if China were able to meet its own proposed 45 per cent carbon intensity cut, the country would cut 1.2 GtCO 2 of emissions in 2020 from its baseline levels, as is required under the ambitious $450 \mathrm{ppm}$ scenario. That is equivalent to 31.6 per cent of what the world would need to do in 2020 under the 450 ppm scenario - a share higher than China's share of the world's total carbon dioxide emissions (28 per cent in 2020). Clearly, the high end of China's target, if met, aligns with the specified obligation that China needs to fulfil under the 450 ppm scenario.

Arguably, China will claim to meet its carbon intensity target as long as it cuts its carbon intensity by 40 per cent in the period 2006-20. This raises the stringency issue of this proposed intensity reduction. The IEA (2009b) estimates that national policies under consideration in China will bring reductions of about 1 GtCO2 in 2020. This suggests a carbon intensity reduction of 43.6 per cent in 2020 relative to its 2005 levels, implying that the low end of China's carbon intensity target is conservative. Is it a big deal to emphasise this few percentage points difference? It might not matter much for a small country, but for China it matters a great deal.

Is there room for China to achieve additional reductions in carbon intensity by 2020, beyond its own targets? It would be hard, but not impossible. Given that many of the policies considered in the World Energy Outlook 2009 that will cut emissions of $1 \mathrm{GtCO} 2$ in 2020 from its baseline levels are not particularly climate motivated, China could accelerate the speed, and scale up the implementation, of such policies and enact additional policies with explicit considerations of climate mitigation and adaptation. This would bring additional reductions in China's carbon intensity.

What, then, is the yardstick or bound on the energy and carbon intensity of the Chinese economy in 2020? Assuming that China's economy grows at the annual average rate of 7.6 per cent used for the World Energy Outlook 2009 and that China is able to limit the growth of energy use to half the growth rate of the economy between 2006 and 2020, China's energy use per unit of GDP would be cut by 42 per cent by 2020, relative to its 2005 levels. This back- 
of-the-envelope calculation assumes an income elasticity of energy demand of 0.5 between 2006 and 2020 - as it was roughly during the 1980s and 1990s. Given that China experienced faster energy consumption growth than economic growth between 2002 and 2005, this elasticity is, however, likely to be higher in the future, which will result in higher emissions growth. Thus, a 42 per cent cut in China's energy intensity by 2020 relative to 2005 levels is considered an upper bound on China's energy intensity target. With carbon-free energy meeting 7.1 per cent of China's total energy needs in 2005 (NBS 2009) and that share mandated to be increased to 15 per cent, this 42 per cent cut in energy intensity is equivalent to a 50 per cent cut in carbon intensity between 2006 and 2020, implying that there is room for China to increase its own proposed carbon intensity reduction. China should therefore aim for a 46-50 per cent cut in its carbon intensity in the period 2006-20. The Intergovernmental Panel on Climate Change (IPCC 2007) recommends developing countries as a group limit their greenhouse gas emissions to 15-30 per cent below their baseline levels by 2020 . This $46-50$ per cent carbon intensity reduction will lead to China's emissions reductions of 15-21 per cent compared with its baseline levels in 2020. That will put China's absolute emissions reductions very much within the IPCC's recommended levels.

\section{China's energy and GDP statistics: reliability issues}

Having an ambitious commitment is one thing. Fulfilling that commitment is another. While the level of China's commitments is crucial in affecting the level and ambition of commitments from other countries, it is more important to know whether the claimed carbon emissions reductions are real. This raises reliability issues concerning China's statistics on energy and GDP.

China is not known for the reliability of its statistics (for example, Rawski 2001). China's refusal to budge on demands by the United States and other industrialised countries for greater transparency and checks at Copenhagen was cited by negotiator after negotiator as a key block to reaching a deal. As long as China's pledges are in the form of carbon intensity, the reliability of emissions and GDP data matter.

Assuming the fixed carbon dioxide emissions coefficients that convert consumption of fossil fuels into carbon dioxide emissions, the reliability of emissions data depends on energy consumption data. Unlike the energy data in the industrial product tables in the China Statistical Yearbook, the statistics on primary energy production and consumption are usually revised in the year after their first appearance. As would be expected, the adjustments made to 
production statistics are far smaller than those made to consumption statistics, because it is easier to collect information on the relatively small number of energy producers compared with the large number of energy consumers. Table 6.3 shows the preliminary and final values for total primary energy consumption and coal consumption in China between 1990 and 2008. Until 1996, revisions of total energy use figures were several times smaller than in the late 1990s and early 2000s. The preliminary figures for total energy use in 1999-2001 were revised upwards by 8-10 per cent. In all three years, these adjustments were driven by upward revisions of 8-13 per cent made to the coal consumption figures to reflect unreported coal production mainly from small, inefficient and highly polluting coalmines. These coalmines were ordered to shut down in a widely publicised nationwide campaign beginning in 1998, although many had reopened because in many cases local governments had pushed back to preserve local jobs and generate tax revenues as well as for personal pay-offs. In recent years, preliminary figures for energy use are almost the same as the final reported ones.

Table 6.3 Preliminary and final values for total primary energy consumption and coal consumption in China, 1990-2008

\begin{tabular}{l|ccc|ccc}
\hline \multirow{2}{*}{ Year } & \multicolumn{4}{|l|}{ Total primary energy consumption } & \multicolumn{3}{|l}{ Total coal consumption } \\
\cline { 2 - 6 } & $\begin{array}{ccccc}\text { Preliminary } \\
\text { value(mtce) }\end{array}$ & $\begin{array}{c}\text { Final } \\
\text { value } \\
\text { (mtce) }\end{array}$ & $\begin{array}{c}\text { Adjustment } \\
\text { (\%) }\end{array}$ & $\begin{array}{c}\text { Preliminary } \\
\text { value } \\
\text { (mtce) }\end{array}$ & $\begin{array}{c}\text { Final } \\
\text { value } \\
\text { (mtce) }\end{array}$ & $\begin{array}{c}\text { Adjustment } \\
\text { (\%) }\end{array}$ \\
\hline 1990 & 980 & 987 & 0.7 & 741 & 752 & 1.5 \\
1991 & 1023 & 1038 & 1.4 & 777 & 790 & 1.6 \\
1992 & 1089 & 1092 & 0.2 & 816 & 826 & 1.3 \\
1993 & 1117 & 1160 & 3.8 & 814 & 866 & 6.5 \\
1994 & 1227 & 1227 & 0.0 & 921 & 921 & 0.0 \\
1995 & 1290 & 1312 & 1.7 & 968 & 979 & 1.1 \\
1996 & 1388 & 1389 & 0.1 & 1041 & 1038 & -0.3 \\
1997 & 1420 & 1378 & -3.0 & 1044 & 988 & -5.3 \\
1998 & 1360 & 1322 & -2.8 & 974 & 920 & -5.5 \\
1999 & 1220 & 1338 & 9.7 & 819 & 925 & 13.0 \\
2000 & 1280 & 1386 & 8.2 & 858 & 939 & 9.5 \\
2001 & 1320 & 1432 & 8.5 & 884 & 955 & 8.0 \\
2002 & 1480 & 1518 & 2.6 & 978 & 1006 & 2.9 \\
2003 & 1678 & 1750 & 4.3 & 1126 & 1197 & 6.3 \\
2004 & 1970 & 2032 & 3.2 & 1334 & 1382 & 3.6 \\
2005 & 2233 & 2247 & 0.6 & 1539 & 1553 & 0.9 \\
2006 & 2463 & 2463 & 0.0 & 1709 & 1709 & 0.0 \\
2007 & 2656 & 2656 & 0.0 & 1846 & 1846 & 0.0 \\
2008 & $2850 *$ & & & $1958 *$ & & \\
\hline
\end{tabular}

mtce $=$ million tonnes of coal equivalent

* Data for energy and coal consumption in 2008 are preliminary values.

Source: Based on National Bureau of Statistics (NBS) various years, China Statistical Yearbook, China Statistics Press, Beijing. 
Similarly, China first releases its preliminary GDP figures and then revises them. The revised GDP figures for the years 2005-08 are subject to further verification based on the second agricultural census released in February 2008 and the second nationwide economic census released in December 2009. With upward revisions of both GDP and the share of services, there is a big variation between the preliminary value of China's energy intensity and the final reported one. As shown in Table 6.4, such revisions lead to a differential between preliminary and final values as large as 45.5 per cent for energy intensity in 2006 . With the government's continuing efforts to improve the quality of China's statistics, such differentials will become less important.

Table 6.4 Reduction in China's energy intensity: preliminary value versus final value (per cent)

\begin{tabular}{ccccc}
\hline Year & Preliminary value & Revised value & Final value & $\begin{array}{c}\text { Differential between } \\
\text { preliminary and } \\
\text { final values }\end{array}$ \\
\hline 2006 & 1.23 (March 2007) & 1.33 (July2007) & 1.79 (July 2008) & 45.5 \\
2007 & 3.27 (March 2008) & 3.66 (July 2008) & 4.04 (June2009) & 23.5 \\
2008 & 4.59 (June 2009) & $5.2^{\text {a }}$ (Dec 2009) & & 13.3 \\
2009 & $3.98^{\text {b } \text { (March 2010) }}$ & & & \\
\hline
\end{tabular}

a) Based on China's revised 2008 GDP from the second nationwide economic census, which raised the growth rate of GDP to 9.6 per cent from the previously reported 9 per cent for that year and the share of services in GDP.

b) Author's own calculation based on the NDRC's reporting that China's energy intensity was cut by 14.38 per cent in the first four years of the eleventh five-year plan relative to its 2005 levels (Xinhua Net 2010, 'NDRC: the 1lth five-year pollution-cutting goals met ahead of the schedule', Xinhua Net, 10 March, $<$ http://news.sina.com.cn/c/2010-03-10/152019834186.shtml >).

Note: The dates when the corresponding data were released are in parentheses.

From the preceding discussion, it follows that GDP figures are even more crucial to the impacts on energy or carbon intensity than are energy consumption and emissions data. In Copenhagen, China eventually compromised to agree to open its emissions data to international consultation and analysis. The European Union has identified building a robust and transparent emissions and performance accounting framework as a key element of implementing the Copenhagen Accord (European Commission 2010). How all this will be worked out remains to be seen. China has not agreed to open its GDP figures to international consultation and analysis. As long as China's commitments are in the form of carbon intensity, establishing a robust and transparent emissions and performance accounting framework is helpful, but not enough to remove international concern about the reliability of China's commitments. The aforementioned revisions of China's GDP figures reflect part of the government's continuing efforts to improve the accuracy and reliability of China's statistics on economic activity. They are certainly not being calculated to make the energy intensity indicator look good to 
the government's advantage, although practically they do benefit this indicator. Still, such revisions have huge implications for meeting China's existing energysaving goal in 2010 and its proposed carbon intensity target in 2020.

\section{Central-local relations, energy savings and emissions reductions}

Given China's vast size and diversity, it is impossible for the central government in Beijing to operate single-handedly in pursuing nationwide energy savings and environmental outcomes. The ability of, and incentives for, lower-level governments to effectively implement energy-saving and pollution-cutting policies is therefore critical, particularly since the past three decades of economic reforms have witnessed a shift in the control over resources and decision making to local governments and enterprises.

This devolution of decision making to local governments has placed environmental stewardship in the hands of local officials. They are concerned primarily with economic growth, because under the current evaluation criterion for officials in China, local officials typically have been promoted based on how quickly they expand their local economies. This distorted incentive system tempts officials to disregard the environmental costs of growth. Moreover, the current fiscal system in China plays a part in driving local governments to seek higher GDP growth because that system makes it hard to reconcile the interests of the central and local governments (Zhang 2007c, 2007d, 2009a). Since the Tax Sharing System (TSS) was adopted in China in 1994, taxes are grouped into those collected by the central government, those collected by local governments and those shared between the central and local governments. All those taxes that have steady sources and broad bases and are easily collected - such as the consumption tax, tariffs and the vehicle purchase tax-are assigned to the central government. The VAT and income tax are split between the central and local governments, with 75 per cent of VAT and 60 per cent of income tax going to the central government. As a result, central government revenue increased by 200 per cent in 1994 relative to its 1993 level. This led the central government's share in total government revenue to go up to 55.7 per cent in 1994 from 22 per cent in the previous year, while its share in total government expenditure rose by just 2 per cent. By 2008, local governments accounted for only 46.7 per cent of total government revenue, while their expenditure accounted for 78.7 per cent of the total government expenditure in China. To cover their expenditure for culture and education, supporting agricultural production, social security and so on, local governments have little choice but to focus on expanding local 
production. This in turn enables them to enlarge their tax revenue by collecting a range of taxes, including urban maintenance and development tax, contract tax, arable land occupation tax and urban land-use tax.

Another example of distortions associated with the tax-sharing scheme in China is related to differentiated tariffs. The NDRC ordered provincial governments to raise power tariffs for eight energy-guzzling industries from 1 October 2006 onwards (Table 6.5), but many local governments failed to implement the differentiated tariffs that charged more for companies classified as 'eliminated types' or 'restrained types' in these industries, with 14 of them even continuing to offer preferential power tariffs for such industries. The reason for this failure is the lack of incentives for local governments to implement this policy, because all of the revenue collected from these additional charges goes to the central government. To provide incentives for local governments, these revenues should be assigned to local governments, with the central government requiring local governments to use the revenue specifically for industrial upgrading, energy savings and emissions cutting (Zhang 2007c, 2007d, 2008, 2009a).

Table 6.5 Differentiated tariffs for eight energy-guzzling industries in China (RMB/kW.h)

\begin{tabular}{l|l|cccc}
\hline \multicolumn{2}{l|}{} & $\begin{array}{c}\text { Existing } \\
\text { additional } \\
\text { charge }\end{array}$ & $\begin{array}{c}\text { Additional } \\
\text { charge since } \\
\mathbf{1} \text { October } \\
\mathbf{2 0 0 6}\end{array}$ & $\begin{array}{c}\text { Additional } \\
\text { charge since } \\
\text { 1 January } \\
\mathbf{2 0 0 7}\end{array}$ & $\begin{array}{c}\text { Additional } \\
\text { charge since } \\
\text { 1 January } \\
\mathbf{2 0 0 8}\end{array}$ \\
\hline $\begin{array}{l}\text { Eight energy- } \\
\text { guzzling } \\
\text { industries }\end{array}$ & $\begin{array}{l}\text { Eliminated } \\
\text { types }\end{array}$ & 0.05 & 0.10 & 0.15 & 0.20 \\
\cline { 2 - 6 } & $\begin{array}{l}\text { Restrained } \\
\text { types }\end{array}$ & 0.02 & 0.03 & 0.04 & 0.05 \\
\hline
\end{tabular}

Source: National Development and Reform Commission (NDRC) 2006b, Suggestions for improving the policy on differentiated tariffs, September, National Development and Reform Commission, Beijing, <http://www.gov.cn/zwgk/2006-09/22/content_396258.htm>

The evidence above suggests the need to carefully examine those objective and subjective factors that lead to the lack of local officials' cooperation on environmental protection and to provide the right incentives for cooperation. One way to ensure local officials realise that they should take the environmental dimensions of their jobs seriously is developing criteria that incorporate energy conservation and environmental performance into the overall evaluation of local officials' performances. As discussed earlier, to ensure the energy-saving goal under the 'Top 1000 Enterprises Energy Conservation Action Program' is reached, achieving energy efficiency improvements has become a criterion for job performance evaluations of the heads of these enterprises. This performancebased approach should be strengthened and extended to ensure that local officials are held accountable for energy savings and pollution cutting in their 
regions. The evaluation of local officials should abandon the sole focus on GDP. Instead, evaluation needs to look not only at the economic growth of a region, but even more at the model and quality of its development. There are some encouraging signs in this direction, but they fall far short of the needs, given the huge challenges China is facing.

Alleviating the financial burden of local governments is another avenue to provide incentives for them to focus on objectives beyond economic growth alone. Enlarging their tax revenue is the key to helping them cover a disproportionate amount of the aforementioned government expenditure. The central government needs to cultivate steady and sizeable sources of revenue for local governments. Enacting property taxes or real estate taxes for local governments is urgently needed. In the TSS adopted in 1994, resource taxes onshore are assigned to local governments, while the central government collects revenue from resource taxes offshore. Currently, resource taxes in China are levied on the basis of the extracted volume of resources. Starting in 1984, resource taxes have been levied at RMB2-5 per tonne of raw coal and RMB8/t of coking coal, with the weighted average of RMB3.5/t of coal. For crude oil, the corresponding tax is levied at RMB8-30/t. While the prices of coal and oil have increased significantly since 1984, the levels of their resource taxes have remained unchanged for the past 25 years. In addition, current resource taxes are levied on only seven types of resources, including coal, oil and natural gas. This coverage is too narrow, falling far short of what is required to conserve resources and protect the environment. Thus, broadening the current coverage of resource taxation and significantly increasing the levied level based on revenues rather than volumes will also help to increase local governments' revenues while contributing to environmental conservation.

\section{Conclusions}

China achieved a quadrupling of its GDP with only a doubling of energy consumption between 1980 and 2000. Since 2002, however, the country has experienced faster energy consumption growth than economic growth. To reverse this trend, China has incorporated for the first time in its five-year economic plan an input indicator as a constraint - requiring that energy use per unit of GDP be cut by 20 per cent during the eleventh five-year period running from 2006 to 2010. This is widely considered an important step towards building a harmonious society through scientific development. Despite significant efforts towards saving energy, reducing pollution and promoting the widespread use of renewable energy in the past four years, China has had limited success to date in achieving this goal. 
While facing this great challenge at home and international pressure from inside and outside international climate negotiations to be more ambitious in limiting its greenhouse gas emissions, just before the Copenhagen climate summit, China pledged to cut its carbon intensity by $40-45$ per cent by 2020 relative to its 2005 levels. This unilateral commitment clearly indicates China's determination to further decouple its carbon emissions from economic growth. The proposed carbon intensity target certainly does not just represent business as usual, as some Western scholars have argued, because even the lower end of that target represents a deviation of 4.8 per cent below the World Energy Outlook 2009 baseline levels, not to mention a deviation of 12.7 per cent below the World Energy Outlook 2009 baseline levels at the higher end. On the other hand, national policies under consideration in China before the announcement of its carbon intensity target would already have led to a carbon intensity reduction of 43.6 per cent in 2020 relative to its 2005 levels. Given that China is already the world's largest carbon emitter and its share in the world's total emissions continues to rise, even a few additional percentage point reductions in its carbon intensity reduction have important implications for global emissions. It is hard, but not impossible for China to increase its own proposed carbon intensity reduction target. We suggest that China should aim for a 46-50 per cent cut in its carbon intensity in the period 2006-20. That would put China's absolute emissions reductions very much at the IPCC's recommended levels for developing countries.

China's proposed carbon intensity target needs not only to be seen as ambitious, but more importantly it needs to be credible. Ascertaining whether or not it is credible involves two issues. One is whether the claimed carbon emissions reductions themselves are real. This raises reliability issues concerning China's statistics on energy and GDP, given that China is not known for the reliability of its statistics. China's compromise at Copenhagen to agree to open its emissions data to international consultation and analysis is a start, although it remains to be seen how this will work in practice. As long as China's commitments are in the form of carbon intensity, establishing a robust and transparent emissions and performance accounting framework is helpful, but not enough to remove international concern about the reliability of China's commitments. The revisions of China's GDP figures and energy consumption in recent years reflect part of the government's continuing efforts to improve the accuracy and reliability of China's statistics on economic activity and energy use. Such revisions show that GDP figures are even more crucial to the impacts on energy or carbon intensity than are energy consumption and emissions data. They also have huge implications for meeting China's existing energy-saving goal in 2010 and its proposed carbon intensity target in 2020. 
Another issue is whether China is really able to achieve its target, given that China has faced and continues to face great difficulty meeting its own 20 per cent energy-saving goal in 2010. China needs to further strengthen existing policies and measures towards energy savings. China has increased its prices of gasoline and diesel and cut its total energy subsidies in recent years to provide incentives for efficient fuel use and adoption of clean technologies that reduce emissions at sources. Although this is encouraging, removing such subsidies is but a first step in getting the energy prices right. Further steps include incorporating the cost of resources themselves to reflect their scarcity and internalising the costs of externalities. More importantly, China needs to significantly scale up its efforts towards strengthening industrial restructuring in order to keep the frenzied expansion of highly energy-consuming, highly polluting and resourceintensive industries under control. Moreover, given that China has shifted control over resources and decision making to local governments during the past three decades, it is also crucial to ensure that local governments act in accordance with centrally directed policies and have adequate funding to achieve their own policy goals.

Finally, it should be emphasised that enacting the aforementioned policies and measures targeted for meeting China's existing energy-saving goal in 2010 and its proposed carbon intensity target in 2020 signals the goodwill and determination of China's leaders. To really achieve the desired outcomes, however, requires strict implementation and coordination of these policies and measures, as the aforementioned development of wind power and its coordination with the planning and construction of power grids have exemplified. This will be a decisive factor in determining the prospects for whether China will achieve its carbon intensity target. There is no doubt that achieving this target poses a significant challenge for China. The whole world is waiting to see whether China can turn this challenge into a win-win outcome for China and for global climate change.

\section{References}

An, F. and Sauer, A. 2004, Comparison of Passenger Vehicle Fuel Economy and GHG Emission Standards Around the World, December, Pew Center on Global Climate Change, Arlington, Va, http://www.pewclimate.org/docUploads/ Fuel Economy and GHG Standards_010605_110719.pdf

Beijing Municipal Commission of Development and Reform (BMCDR) 2006, The 11 th Five-Year Development Program for Energy Conservation in the Building 
Sector of Beijing Municipality, 8 September, Beijing Municipal Commission of Development and Reform, <http:/www.beijing.gov.cn/zfzx/ghxx/sywgh/ t662751.htm>

Chen, Y. H. 2010, 'NEA mandated wind power to be hooked up with the grids as a result of China's emissions reduction commitments', 21st Century Business Herald, 30 April, <http://finance.sina.com.cn/chanjing/ cyxw/20100430/02257855241.shtml>

Cyranoski, D. 2009, 'Beijing's windy bet', Nature, vol. 457, no. 7228, pp. 372-4.

Earth Policy Institute 2008, Global Wind Power Capacity Reaches 100,000 Megawatts, 4 March, Earth Policy Institute, Washington, DC, <http://www. earth-policy.org/Indicators/Wind/2008.htm>

Energy Information Administration (EIA) 2004, International Energy Outlook 2004, US Energy Information Administration, Washington, DC.

European Commission 2007a, Communication from the commission to the European Council and the European Parliament: an energy policy for Europe, $\operatorname{COM}(2007)$ 1 final, 10 January, European Commission, Brussels, <http://ec.europa.eu/ energy/energy_policy/doc/01_energy_policy_for_europe_en.pdf>

European Commission 2007b, Energy for a Changing World: An energy policy for Europe - the need for action, European Commission, Brussels, <http:// ec.europa.eu/energy/energy_policy/doc/2007_03_02_energy_leaflet_ en.pdf $>$

European Commission 2010, International climate policy post-Copenhagen: acting now to reinvigorate global action on climate change, $\operatorname{COM}(2010) 86$ final, 9 March, European Commission Brussels, <http://ec.europa.eu/environment/ climat/pdf/com_2010_86.pdf>

Garnaut, R. 2008, Climate Change Review Report, Cambridge University Press, Cambridge

Garnaut, R., Jotzo, F., Howes, S. and Sheehan, P. 2009, 'The Implications of Rapid Development for Emissions and Climate Change Mitigation', in D. Helm and C. Hepburn (eds), The Economics and Policy of Climate Change, Oxford University Press, Oxford.

Global Wind Energy Council 2010, Global Wind 2009 Report, March, Global Wind Energy Council, Brussels, http://www.gwec.net/fileadmin/documents/ Publications/Global_Wind_2007_report/GWEC_Global_Wind_2009_ Report_LOWRES_15th. percent20Apr..pdf. 
Huang, Q. L. 2008, 'Cleaner and more efficient coal-fired power generation technologies in China', Huadian Technology, vol. 30, no. 3, pp. 1-8.

International Energy Agency (IEA) 2007, World Energy Outlook 2007, International Energy Agency, Paris.

International Energy Agency (IEA) 2009a, Cleaner Coal in China, International Energy Agency, Paris.

International Energy Agency (IEA) 2009b, World Energy Outlook 2009, International Energy Agency, Paris.

Intergovernmental Panel on Climate Change (IPCC) 2007, Climate change 2007: mitigation of climate change, Working Group III Contribution to the Fourth Assessment Report, Cambridge University Press, Cambridge.

Levi, M. 2009, Assessing China's Carbon Cutting Proposal, 30 November, Council on Foreign Relations, New York.

National Bureau of Statistics (NBS) 2009, China Statistical Yearbook 2009, China Statistics Press, Beijing.

National Bureau of Statistics (NBS) various years, China Statistical Yearbook, China Statistics Press, Beijing.

National Bureau of Statistics (NBS), National Development and Reform Commission (NDRC) and National Energy Administration (NEA) 2008, Bulletin on energy use per unit of GDP and other indicators by region, 14 July, National Bureau of Statistics, National Development and Reform Commission and National Energy Administration, Beijing, <http://www.stats.gov.cn/ tjgb/qttjgb/qgqttjgb/t20080714_402491870.htm>

National Bureau of Statistics (NBS), National Development and Reform Commission (NDRC) and National Energy Administration (NEA) 2009, Bulletin on energy use per unit of GDP and other indicators by region, 30 June, National Bureau of Statistics, National Development and Reform Commission and National Energy Administration, Beijing, <http://www.stats.gov.cn/ tjgb/qttjgb/qgqttjgb/t20090630_402568721.htm>

National Bureau of Statistics (NBS), National Development and Reform Commission (NDRC) and Office of The National Energy Leading Group 2007, Bulletin on energy use per unit of GDP and other indicators by region, 12 July, National Bureau of Statistics, National Development and Reform Commission and Office of The National Energy Leading Group, Beijing, <http://hzs.ndrc. gov.cn/newjn/t20070809_152873.htm> 
National Development and Reform Commission (NDRC) 2006a, The top 1000 enterprises energy conservation action program, NDRC Environment and Resources [2006] no. 571 (April), National Development and Reform Commission, Beijing, <http://hzs.ndrc.gov.cn/newzwxx/t20060414_66220. htm>

National Development and Reform Commission (NDRC) 2006b, Suggestions for improving the policy on differentiated tariffs, September, National Development and Reform Commission, Beijing, <http://www.gov.cn/ zwgk/2006-09/22/content_396258.htm>

National Development and Reform Commission (NDRC) 2008a, China had decommissioned fossil fuel-fired small plants with a total capacity of 25.87 GW since January 1, 2006, 14 July, National Development and Reform Commission, Beijing, <http://nyj.ndrc.gov.cn/sdyx/t20080714_224054. htm $>$

National Development and Reform Commission (NDRC) 2008b, A circular on the evaluation of energy saving in 2007 of the top 1000 enterprises, 27 August, National Development and Reform Commission, Beijing, <http://hzs.ndrc. gov.cn/jnxd/t20080903_234934.htm>

National Development and Reform Commission (NDRC) 2009, A circular on improving on grid feed-in tariffs for wind power, 22 July, National Development and Reform Commission, Beijing, <http://www.fenglifadian. com/zhengce/512169872.html>

National Development and Reform Commission (NDRC) and National Bureau of Statistics (NBS) 2007, Bulletin on energy use of the top 1000 enterprises, 18 September, National Development and Reform Commission and National Bureau of Statistics, Beijing, <http://www.sdpc.gov.cn/zcfb/ zcfbgg/2007gonggao/W020071009598162122784.pdf>

Pew Charitable Trusts 2010, Who's Winning the Clean Energy Race?: Growth, competition and opportunity in the world's largest economies, March, Pew Charitable Trusts, Philadelphia, http://www.pewtrusts.org/uploadedFiles/ wwwpewtrustsorg/Reports/Global_warming/G-20percent20Report. $\mathrm{pdf} ? \mathrm{n}=5939$

Qiu, J. 2009, 'China's climate target: is it achievable?', Nature, vol. 462, pp. $550-1$.

Rawski, T. G. 2001, 'What is happening to China's GDP statistics?', China Economic Review, vol. 12, no. 4, pp. 347-54. 
Wang, P. and Ye, Q. 2009, 'China about to release new energy development plan by the end of 2009', Xinhua Net, 9 August, <http://news.sina.com.cn/ c/2009-08-09/140918397192.shtml>

Zhang, Z. X. 2000, 'Can China afford to commit itself to an emissions cap? An economic and political analysis', Energy Economics, vol. 22, no. 6, pp. $587-614$.

Zhang, Z. X. 2003, 'Why did the energy intensity fall in China's industrial sector in the 1990s? The relative importance of structural change and intensity change', Energy Economics, vol. 25, no. 6, pp. 625-38.

Zhang, Z. X. 2005, Sustainable energy development in China: challenges ahead to 2020, Keynote address at the International Conference on Staying Ahead of the Energy Scenarios, Bangkok, 11 November.

Zhang, Z. X. 2007a, 'China's reds embrace green', Far Eastern Economic Review, vol. 170, no. 5, pp. 33-7.

Zhang, Z. X. 2007b, 'China is moving away from the pattern of "develop first and then treat the pollution"', Energy Policy, vol. 35, pp. 3547-9.

Zhang, Z. X. 2007c, Greening China: can Hu and Wen turn a test of their leadership into a legacy?, Presented at the Plenary Session on Sustainable Development at the first Harvard College China-India Development and Relations Symposium, New York, 30 March - 2 April.

Zhang, Z. X. 2007d, Energy and environmental policy in mainland China, Keynote address at the Cross-Straits Conference on Energy Economics and Policy, organised by the Chinese Association for Energy Economics, Taipei, 7-8 November.

Zhang, Z. X. 2008, 'Asian energy and environmental policy: promoting growth while preserving the environment', Energy Policy, vol. 36, pp. 3905-24.

Zhang, Z. X. 2009a, 'Is it fair to treat China as a Christmas tree to hang everybody's complaints? Putting its own energy-saving into perspective', Energy Economics, 3 December, <doi:10.1016/j.eneco.2009.03.012>

Zhang, Z. X. 2009b, 'In what format and under what timeframe would China take on climate commitments? A roadmap to $2050^{\prime}$, International Environmental Agreements: Politics, law and economics, Social Sciences Research Network, $<$ http://papers.ssrn.com/sol3/papers.cfm?abstract_id=1415123>

Zhang, Z. X. 2009c, 'The US proposed carbon tariffs, WTO scrutiny and China's responses', International Economics and Economic Policy, DOI:10.1007/ s10368-010-0166-8. 
Zhang, Z. X. 2009d, China in the transition to a low-carbon economy, Invited presentation at the Second International Colloquium on Sustainable Growth, Resource Productivity and Sustainable Industrial Policy, Wuppertal, Germany, 10-12, September, <http://www.eastwestcenter.org/fileadmin/ stored/pdfs//econwpl09.pdf>

Zheng, X. and You, S. 2007, Heat reform in Tianjin China, Unpublished manuscript, School of Environmental Engineering, Tianjin University. 